\title{
Alash Movement in Historic Memory: Historiographic Overview of Sources from President's Archive of Kazakhstan
}

DOI: $10.31551 / 2410-2725-2018-4-3-412-426$

\author{
Alimgazinov Kayrat \\ Deputy Director of the Archive of the President of the Republic of Kazakhstan, Doctor of Historical Sci- \\ ences. Republic of Kazakhstan, 050000, Almaty, Dostyk Avenue, 875.
}

\section{Chilikova Yevgeniya}

Head of the Department of scientific publication of documents of the Presidential Administration of the Republic of Kazakhstan. Republic of Kazakhstan, 010000, Astana, Mangilik El, 6 (Government House).

\section{Ualtayeva Altyn Slamkaydarovna}

Candidate of historical sciences, the Associated Professor, Leading scientific Employee of the Ch. Valikhanov Institute of History and Ethnology. Republic of Kazakhstan, 480021, Almaty, Shevchenko str, 28. E-mail: altyn.lazzat@mail.ru

\begin{abstract}
As some more documents on Kazakhstan in the X20th century has been declassified, new historical evidence on the Alash movement are available for further scholarly inquiry. The authors overview the complex materials from the President's Archive of Kazakhstan. The analysis is focused on the records of the processes and events relating to the establishment of the Soviet power made by the witnesses and commentators including those providing new information on the activities of the Alash party's and Alash national intelligentsia. The authors also examine the memoires written several decades later by the descendants of K. Dosmukhamedov, M. Zhumabayev and other prominent figures who had been repressed by the Stalin regime.

Keywords: archival sources; memoires; history of Alash; collection documents.
\end{abstract}

\section{Тарихи жады кеңістігіндегі Алаш қозғалысы (Қазақстан Республикасы Президенті Мұрағаты материалдарына деректанулық және археографикалық шолу)}

\section{Әлімғазинов Қайрат}

тарих ғылымдарының докторы, Қазақстан Республикасы Президенті Мұрағаты директорының орынбасары. Қазақстан Республикасы, 050000, Алматы қ, Достык даңғ., 87Б.

\section{Чиликова Евгения}

Қазақстан Республикасы Президенті Әкімшілігі Құжаттардың ғылыми жариялануы басқармасының басшысы. Қазақстан Республикасы, 010000, Астана қ., Мәңгілік ел, кош. 6 (Үкімет Үйі).

\section{Уалтаева Алтын Слямкайдаровна}

тарих ғылымдарының кандидаты, ҚР БҒМ ҒК Ш.Ш. Уәлиханов атындағы Тарих және этнология институтының аға ғылыми қызметкері. Қазақстан Республикасы, 480021, Алматы қ., Шевченко көш., 28. E-mail: ualtayeva_altyn@mail.ru.

\begin{abstract}
Аңдатпа. Мұрағатшылардың құжаттарды жариялау жұмысының нәтижесінде зерттеушілерге XX ғасыр басындағы тың дереккөздер, оның ішінде Алаш қозғалысы тарихына қатысты материалдар қолжетімді болып отыр. Мақалада ҚР Президентінің Мұрағатында сақталған материалдар кешенін қалыптастыру ісіне шолу жасалып, жарияланған құжаттық жинақтардың мазмұны қарастырылған. Сондай-ақ Алаш партиясының қызметі мен Алаш зиялылары туралы мәліметтерді қамтитын сол дәуірдің естеліктерін ғана емес, қуғын-сүргінге ұшыраған Х. Досмұхамедұлы, М. Жұмабаев және т.б. ұрпақтарының бірнеше жылдардан кейін жазылған мемуарлық туындыларын талдауға баса назар аударылған.

Түйінді сөздер: мұрағат дереккөздері; естеліктер; Алаш тарихы; құжаттар жинағы.
\end{abstract}




\title{
Движение «Алаш» в пространстве исторической памяти (источниковедческий и археографический обзор материалов Архива Президента Республики Казахстан)
}

\author{
Алимгазинов Кайрат \\ доктор исторических наук, заместитель директора Архива Президента Республики Казахстан, \\ Республика Казахстан, 050000, г.Алматы, проспект Достык, 87Б.
}

\section{Чиликова Евгения}

руководитель отдела научной публикации документов Администрации Президента Республики Казахстан. Республика Казахстан, 010000, г. Астана, ул. Мәңгілік Ел, 6 (Дом Правительства).

\section{Уалтаева Алтын Слямкайдаровна}

кандидат исторических наук, ведущий научный сотрудник Института истории и этнологии имени ч.Ч. Валиханова КН МОН РК. Республика Казахстан, 480021, г. Алматы, Шевченко, 28. E-mail: ualtayeva_altyn@mail.ru.

Абстракт. В результате работы архивистов по рассекречиванию документов, исследователям становятся доступными новые массивы источников XX в., в частности по истории движения «Алаш». В статье дается обзор по формированию комплекса материалов, хранящихся ныне в Архиве Президента РК, раскрывается содержание изданных документальных сборников. Внимание уделено разбору не только воспоминаний очевидцев установления советской власти, в которых содержатся сведения о деятельности партии «Алаш» и алашской национальной интеллигенции, но и мемуарных произведений, написанных спустя несколько десятилетий потомками репрессированных X. Досмухамедова, М. Жумабаева и др.

Ключевые слова: архивные источники; воспоминания; история Алаш; документальные сборники.

\section{ӘОЖІ Удк 93/94}

\author{
Тарихи жады кеңістігіндегі Алаш қозғалысы \\ (Қазақстан Республикасы Президенті Мұрағаты материалдарына \\ деректанулық және археографикалық шолу)
}

Кіріспе. ҚР Президентінің Мұрағатындағы құжаттар XX ғасырдың бірінші ширегінің тарихын зерттеуде айрықша деректанушылық қызығушылық тудырады. Мұрағаттың сол кезеңдегі материалдарында тарихи фрактілер мен оқиғалар, сондайақ өткен тарихқа белгілі бір көзқарас қалыптастырған қоғамдық-тарихи режим туралы мәліметтер сақталған. Осы тұрғыда сол дәуірдің естеліктері деректану жұмыстарында айрықша орын алады. Тоталитаризм дәуірінің ақпараттық субъективтік және идеологиялық өнімі зерттеушілердің назарынан тыс қалып келеді, аталған дереккөздер үлесі жеке басқа қатысты болса да, сол кезеңнің жалпы жайкүйін (Тартаковский 1967: 222), замананың «рухы мен тынысын» беруге қабілетті, әрі өткенге замандастар көзімен табиғи көзқарас қалыптастыруға (Волобуев 1997: 4) мүмкіндік береді. XX ғасырдың басындағы Қазақстанның қоғамдық-саяси өмірінің әртүрлі қырларын зерттеуде аталған мұрағат материалдары ашылмаған ақпараттық әлеуетке ие.

Зерттеу әдістері. Жарияланымның әдіснамалық проекциясын френоменологиялық тәсіл, яғни «өткен адамды түсінуге» талпыну арқылы тарихи фактілер мен оқиғаларға интерпретация жүргізу тәсілі құрайды. Қазіргі деректану ісінде аталған әдіснамалық мектепті А.С. Лаппо-Данилевскийдің ілімі ұсынған (Медушевская 1997: 72). Мұрағат көздеріне шолу археографиялық және тарихнамалық тәсілдерге негізделген. Тарихи мәтіндерді зерттеуде логикалық, 
тарихи-салыстырмалы талдау әдістері қолданылды. Бұл мұрағат материалдарын зерттеудің проблемалық-бейімделген міндеттерінен туындады.

XX ғасыр бас кезіндегі саяси тарих материалдарын жинау бойынша Партия тарихының қызметі. Қазан революциясы және БКП (б) тарихы бойынша комиссияны - Партия тарихын ұйымдастырумен 1917-1920 жылдары оқиғалар куәгерлерінің естеліктерін жинауға қатысты жүйелі жұмыстар басталды. Орталық Партия тарихы 1920 жылы алдымен Халық оқу-ағарту комиссариаты жанында, кейін 1921 жылы 1 желтоқсаннан бастап БКП ОК (б)-де бөлім құқығында құрылды. Бұл органның міндеті «Қазан революциясы мен тарихы... партиясына қатысты материалдарды жинау және зерттеу» болды (Пролетарская революция 1923). Қазан революциясы мен азамат соғысы тарихына қатысты материалдарды жинау және оларды сақтау талаптары кеңес өкіметін құрушы В.И. Лениннің пікірінше, бұл материалдар кеңестік Ресей туралы контрреволюциялық буржуазиялық өтірікті әшкерелеуде негізгі дереккөз болып табылады (Вопросы истории1960). Большевиктік тарихты бас қолдаушы әрі идеологі М.И. Покровский сонау 1920 жылдардың басында-ақ, 1917 жылғы революцияның тарихын және одан кейінгі болған оқиғаларды большевиктердің көзімен жазу қажеттігін айтқан. Оның пікірінше, «С пролетарским периодом русской революции, грозит повториться то, что случилось С демократическим ее периодом. Историю движения 1905-1907 г. описали не те, кто делал тогда революцию, а те, кто мешал ее делать. У нас есть меньшевистская история первого восстания русской народной массы против романовского режима, есть попытки кадетской истории, - а со стороны большевиков не было даже и попыток сколь-нибудь выдержанных и последовательных...» (Покровский 1922:5).

Орталық Партия тарихы органының «Пролетарлық революция» журналының бірінші нөмірінің беттерінде Комиссия атынан М.И. Покровский Партия тарихы сияқты орган болашақ ұрпақ үшін «өткеннің ауқымды дүниесін» коммунистік партия тарихын сақтау міндетін атқаруға қабілетті екендігін атап өтіп, үндеу жасады. Бұл ретте естеліктерге айрықша құндылық берілді (Пролетарская революция 1917). Большевиктер партиясының тарихы туралы сөз еткенде, құжаттарда көптеген жайттар көрініс таппағаны айтылды. Міне, осы жерде әсіресе «сол кезеңнің психологиялық және эмоционалдық ауанын беретін кез келген естеліктер, сондай-ақ қолымыздағы жекелеген құжаттардың түсініксіз болуы немесе қате түсіндірілуі мүмкін сол тұстағы байланыстар» құнды болып табылады. «Құжатты бірнеше жылдардан кейін қолға алған адамдар емес, оның қалай туғанын көргендер ғана дәл оқи алады» деп топшылағандар да болды. Үндеуде зерттеушілердің ой топшылаулары бытыраңқы деректік фактілер «оқиғаны білмей жазғанның мемуары тәрізді, бұл жай мемуарлардан нашар көрінеді» делінген. Мұндай тұжырым кейінгі бірнеше жылдары тарихи фрактілердің шынайылығы критерийлерінің бірі оқиға куәгерлерінің сөзімен оны терістеу немесе растауға әкелді. Алғашқы пролетарлық тарихшылар ерекше назар аударған осы мемуарлар болашақ естелік авторларына маңыздылық берді. Осыған орай тарихи оқиғаларға қатысушы-ларды тарихи материалдар жинауға қатысу талпынысын күшейтті. Бұл үндеу естеліктерді жүйелі жинаудың бастамасы болды.

1. Партия тарихының Қырғыз бюросы БКП (б) Қырғыз обкомның 1922 жылғы 20 желтоқсандағы қаулысымен ұйымдастырылды ${ }^{1}$. Саяси қозғалыстар мен партиялар тарихына, оның ішінде «Алашқа» қатысты естеліктерді республикадағы социалистік құрылыстың қарсыластары ретінде большевизмнің саяси 
оппоненттерінің идеологиялық диверсияларын әшкерелеу мақсатында қолдануды жоспарланды.

Қатысушыларға хаттар жіберілді, естеліктер төңірегінде кештер ұйымдастырылды, Партия тарихы қызметкерлері осы кешке қатысушылардан «тергеу сұхбатын» жүргізді. «Қатысушылардың естеліктерін осындай тәсілмен жазу ең үздігі деуге болады, - делінген редакцияда. - Өйткені азаматтардың көбісі дерлік тартыншақтықтың, сенімсіздіктің, тіпті жай ғана жаза алмауының салдарынан өздері ешқашан мұндай естеліктер жазбас еді» (Гелис 1925). Сондай-ақ қазақ өлкесіндегі революциялық оқиғаларға байланысты материалдар жинауға айрықша көңіл бөлінді. Осыған байланысты өз естеліктері мен материалдар жіберу өтінішімен С. Сейфуллин, Н. Нұрмақов, Т. Рысқұлов, А. Асылбеков, О. Жандосов, Т. Әйтиев, Ю. Бабаев және тағы басқаларына жазба хаттар жолданды (Красная летопись Туркестана 1923: 3).

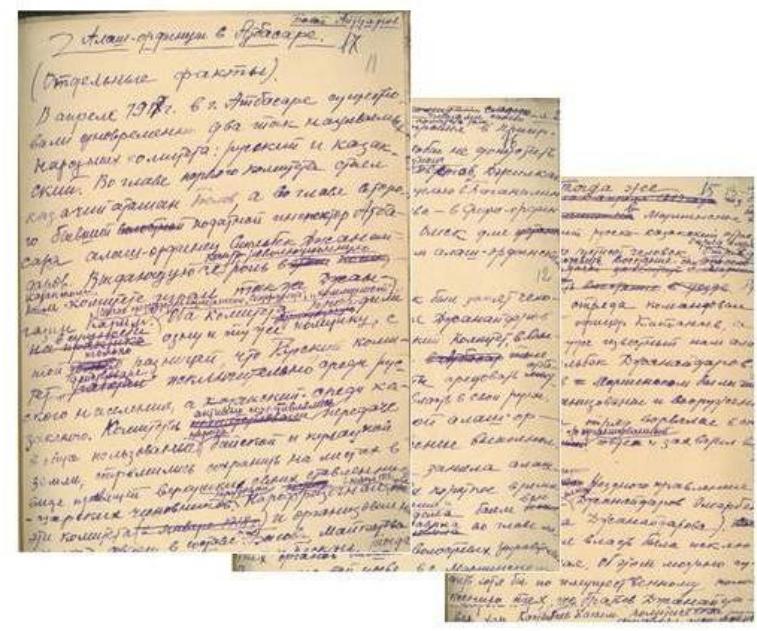

АП РК. Ф.811. Оп.1. Д.3, 7. Рукопись.
[...] В 1918 г. в июне из г. Омска приехал в г. Атбассар председатель областного комитета Алаш-Орды Джанайдаров Сеильбек с определенными заданиями Колчака для восстановления бывшего Атбассарского уездного исполнительного комитета АлашОрды. В восстановленный уездный исполнительный комитет Алаш-Орды были введены Джилкайдаров Ален (председатель), Ансагаев [Абылкасым] (член), Байгарин Казбек. Наряду с этим уездный исполнительный комитет Алаш-Орды своим решением в Атбассарскую уездную чрезвычайную комиссию Колчака выделил в качестве члена Джангазина Карима, а Баржаксина Ахмета назначил начальником уездной милиции $[\ldots]$

1-сурет. Б. Антуаровтың «Алашордашылар Атбасарда» естелігінен үзінді

2. Аталған кезеңде бірқатар құжаттық жинақтар жарияланды: «Қазақстандағы азамат соғысы кезеңінен», «Қазақстан Қазан онжылдығына»².

3. 1926 жылы қарашада БКП (б) Қазақ өлкелік комитетінің III пленумында қабылданған «Алашорда тарихына» қатысты құжаттар жинағын басып шығару туралы шешім тарихи шешім болды. Пленумда Қазақстанның басқарушы партиялық қызметкерлері арасындағы топтармен күрес мәселесі қарастырылды. Тарихшы мамандардың тапшылығына байланысты құжаттар жинағын құрастырушы үшін партия қызметкерлері Н. Мартыненко (БКП (б) Қазақ өлкелік комитетінің Бас саяси-ағарту комитеті меңгерушісінің орынбасары) мен С. Сейфуллин (1926-1927 жж. БКП (б) Қазақ өлкелік комитетінің Тарих партиясына жетекшілік еткен) тартылды (Октябрь в Казахстане 1930).

Азамат соғысы аяқталғаннан кейін С. Сейфуллин «Тар жол, тайғақ кешу» тарихи-мемуарлық романын жазды. Бұл туынды оқиғаға қатысушы ретінде

${ }^{2}$ АПРК. Ф.811. Оп.8. Д.130. Л.1 
автордың естеліктеріне негізделген. Туындының жекелеген тараулары 19221925 жылдары барысында «Қызыл Қазақстан» журналында алғаш рет жарияланды. 1927 жылы кітап болып жарыққа шықты. Автор кітаптың алғы сөзінде «Бұл кітапта Алаш туралы көп әңгіме айтылады. «Алаш» туралы әңгімелер айтылғанда, әлгі айтқандай, сол Алашордада болғандарды айыптамақ ниетімен айтылып отырған жоқ. Тек тарихи мағлұмат ретінде ғана баспа жүзіне шықсын деген оймен айтылды» дейді. Тоталитаризм кезеңіндегі дереккөздерді тарихи-деректік сараптаманың партиялылық қағидатына сәйкес Партия тарихы мемуарлар жазуға негізінен большевиктер тарапынан революцияға қатысушыларды тартты. Алаш қозғалысы қатысушыларының естеліктері мұрағат топтамасында сақталмаған.

Соның нәтижесінде екі кітап жарыққа шықты: 1) А. Богачевтің «Алашорда. 1917-1919 жж. Қазақстандағы ұлттық-буржуазиялық қозғалыс туралы қысқаша тарихи очерк» еңбегі. Очерктен бөлек бұл еңбек 7 құжатты қамтиды (1927 ж.);

2) Н. Мартыненконың құрастыруымен шыққан «Алаш» партиясының қызметіне және Алашорда мемлекеттілігін құруға қатысты құжаттар мен материалдар (1929 ж.). Аталған екі еңбек те кейін сынға ұшырады.

4. Жинақты құрастырушылар арасында білікті мамандардың жетіспеушілігі және олардың теориялық дайындығының әлсіздігі естеліктерді дайындау және оны шығару жұмыстарына әсерін тигізбей қоймады. Естеліктер жинақтарында еңбек материалдарына қысқаша талдау мен сипаттама беретін редакцияның алғысөздері мен авторлар тарапынан фрактілерді растайтын немесе терістейтін дереккөздерге сілтемелер берілмеді. Кейде жинақта жарияланған материалдар сол фрактіге қатысты басқа материалдарға қайшы келді. Партия тарихы бөлімдерінің алғашқы жариялаған материалдарында деректік және мемуарлық дереккөздер бір қатарға қойылып, бір-біріне теңестірілді, соның нәтижесінде естеліктер басым түсті. Мемуарлық дереккөздерді қолдану елдегі мұрағат қорының жаңа қалыптасуымен және көптеген құжаттар зерттеушілерге белгісіз болуымен байланысты болды. Соңғы жағдай жарияланған естеліктер бір оқиғаны баяндау кезінде кейде өзара қайшы болуына себеп болды. Осыған орай жинақтағы авторлардың көзқарастарына қатысты редакцияның түсініктемелері тарихи материалдарды білмеуіне байланысты берілмеді. Авторлардың оқиғаларға берген бағасы оқырмандарды шатастырды, оған қоса жарияланған материалдар үзік-үзік сипат алды. 1930 жылдарға дейінгі материалдар шынайылығының критерийі оқырмандардың (баяндалған оқиғалардың куәгерлері) пікірлері болды. 1928 жылы Партия тарихы желісі бойынша БКП (б) ОК-нің Орта Азия бюросының қаулысында аталған эпизодқа қатысушылар тобы арқылы партия тарихы жұмыстарының негізгі бағыттарын өткізу мақсаттылығына арнайы көңіл бөліндіз.

Осындай қиындықтарға қарамастан, Партия тарихының жергілікті бюросы 1920 жылдардың аяғында құжаттық материалдардың едәуір қорын жинады.

Кеңестік биліктің алғашқы онжылдығында жазылған естеліктерге баяндалған оқиғалардың еркін берілуі тән болды. Авторлар ой пайымдарының шектелмеуі революция және азамат соғысы кезеңінде елдің әлеуметтік-саяси өмірінің кейбір қырларын (жергілікті халықтың Ресейдегі революцияларға көзқарасы, азамат соғысына қатысу деңгейі, қазақ халқының орыстармен ұлтаралық қарым-қатынастарының сипаты және т.б.) суреттеу кезінде көрінген негізгі бағыттарды қарастыруға мүмкіндік берді. Естеліктерді жариялау кезінде негізгі сыншы ретінде сол тұстағы оқиғалардың куәгері - өзге мемуаршы 
шықты. Естеліктерді сыни тұрғыдан талдау (Чиликова 2007: 23-33), археография, сондай-ақ болашақ мемуаршыларға практикалық кеңес беру бойынша (Сейфуллин 1975: 432) алғашқы ғылыми мақалалар 1920-1930 жылдар аралығында шыға бастады. Естеліктер авторларының берген мәліметтеріне сыни тұрғыдан талдау және келтірілген фрактілерді мұрағат материалдарымен салыстырмалы талдау аталған мекемені ғылыми зерттеулер деңгейіне шығарды, бұл тарихи оқиғаларды түсіндіру кезінде обьективтіліктің жоғары деңгейі туралы айтуға мүмкіндік береді.

1930 жылдардан бастап, «Пролетарлық революция» журналында тарихшыларға белгілі И. Сталиннің хаты жарияланғаннан кейін тарихи өткенге қатысты пікірлер алуандығы бірте-бірте жоғала бастады. Партия ұйымдары Л. Кагановичтің айтуынша, «ең салмақты саланың бірі» тарих саласында жіберген қателіктерге байланысты тарихшылар мен мемуаршыларды айыптау процесін қарастыратын резолюция қабылдады (Правда Востока 1928).

«Жалған тарихшыларды» анықтау процесі қазақстандық баспасөз беттерінде де көрініс тапты. Мәселен, «Қазақстан большевигі» журналының беттерінде «Алашорда тарихы бойынша очерктер» және «Кеңестердің Жетісудағы алғашқы қадамдары» еңбектеріндегі С. Брайнин мен Ш. Шафрироның идеялық ұстанымдары айыпталды. Рецензенттердің пікірінше, авторлар «... қазақ бұқарасы Кеңес жолындағы күреске қатыспады деп айыпталған», осылайша өлкедегі алғашқы Кеңестер кулактар болды деген «сафрарлық теорияны» ұстанды (Культурное строительство в Казахстане 1965: 318).

Өз естеліктерін баяндау кезінде редакциялар мен мемуаршылар қаперде ұстайтын арнайы нұсқаулықтар пайда бола бастады. Осындай нұсқаулықтардың бірі ҚР Президентінің Мұрағатында сақтаулы. Ол «естеліктер жазатын партия тарихы мен жолдастарға» арналған. Құжат екі бөлімнен тұрады: 1)

«Естелікті қалай жазу керек және партиялық ұйымдар тарихына қатысты қандай материалдар жинау қажет»; 2) «1917-1920 жж. кезең үшін мұрағаттар мен газеттерден қандай материалдар іздеу керек» (Покровский 1933: 377). Нұсқаулық ережелерді басшылыққа алатын мемуаршылардан мыналар талап етілді: 1) алғашқы партиялық ұйымдар қандай жағдайда және кімнің бастамасымен пайда болғанын баяндау (кадрлардың келуі немесе орнындағы ойлар), оған не түрткі болды; 2) ұйымдар қандай жағдайда және кімнің бастамасымен біріге бастады...; 3) алғашқы ұйымдар мен одан жоғары тұрған ұйымдардың нақты пайда болған күні, нақты және әлеуметтік құрамы; 4) қандай міндеттер қойылды және олар қалай жүзеге асырылды; 5) партиялық ұйымдардың айналасындағы бұқараға әсері қандай болды; 6) партиялық ұйымдарда қандай қателіктер жіберілді; 7) әсіресе А. Дутов пен А. Колчак билігі кезіндегі астыртын жұмыстар кезеңіндегі (1918-1919 жж.) партия ұйымдарының күресін насихаттау.

Осы сызбаны ұстана отырып, 1918 жылғы контрреволюциялық төңкеріске дейінгі және контрреволюция талқандалғаннан кейінгі алғашқы Кеңестердің қызметін оң бағалауы тиіс болатын. Құжаттағы есте қалатын нәрсе - 6-тармақ, онда большевиктер партиясына тән қоғамдық-саяси өмір процестерінің балама түсінігі алып тасталған. Оған қоса, партияның «бас желіден бас тартуын» баяндауды және көрсетуді талап ету, аталған тармақ «оппортунистер», «оңшылдар», сондай-ақ «буржуазиялық ұлшылдар» сияқты әртүрлі тектегі саяси қудалауға өзіндік негіз дайындады. Осыған байланысты, шын мәнінде, заңдық дәрежеге көтере отырып, өзгеше көзқарасты болдырмады. Әскери қимылдарды суреттеу үшін мемуаршылар мына қағидаларды қатаң сақтауы тиіс болды: 1) революциялық партизандық соғыс қашан, қайда және қалай 
пайда болды және оны кім басқарды...; 2) күрес қалай дамыды, қандай күштер болды, олардың ұлттық құрамы, партизандық күштердің қарулануы, қарсыластың артықшылығы...; 3) көтерілістік партизандық күштер қанша уақыт тұрды...; 4) айналадағы ауыл шаруалары тарапынан қандай көзқарас болды, әсіресе жергілікті тұрғындар тарапынан...; 5) ақтардың террорлық жекелеген қимылдарын суреттеу, олардың большевиктерді жәбірлеуі... Егжей-тегжейлі берілген «нұсқама» автордан естеліктер жазуға шығармашылық тұрғыдан келуін талап етпеді. Нұсқаулық сұрақтар түрінде құрылған, оған жауап беру кезінде большевиктер партиясының сүзгісі арқылы оқиғаларды «пайдалы» суреттеуге қол жеткізілді. Мұндай естеліктер тоталитаризм дәуіріндегі тарихи зерттеулер үшін деректанулық негіз құрғаны құпия емес.

Құжаттың екінші бөлімінде келтіретін фактілерді анықтап, тексеруі үшін мемуаршыға қажет мұрағат дереккөздерінің нақты тізбесі берілген. «Мұрағат құжаттарынан: партиялық ұйымдар мен жиналыстардың шешімдерін, еңбекшілерге жасаған үндеулерді (онда кеңестік билік үшін күрес, бұқараны жаулап алу..., меньшевиктердің большевиктермен күресі, жұмыс салтын жақсарту бойынша шаралар) алуға болады». Құжаттардың қажетті көздерінің тізбесінде басқа саяси құрылымдардың қызметі туралы құжаттардың жоқтығы мемуаршыға фрактіге басқаша көзқараспен қарау мүмкіндігіне жол бермеді, бұл автордың болып жатқан оқиғаны қабылдауына әсерін тигізбей қоймады.

1931 жылы республикада ҚазЦИК жанынан Марксизм-ленинизм институты құрылды (бұдан әрі - Институт). 1934 жылы Институт, Партия тарихы және БКП (б) Бірыңғай партиялық мұрағат фрилиалының базасында БКП (б) Қазақ өлкелік комитеті бөлімінің құқығында Қазақстан Маркс-Энгельс-Ленин институты құрылды. Аталған институт партия тарихы жинаған құжат топтамаларының заңды мұрагеріне айналды. 1927 жылы осынау мұра жалпы көлемі 4 мың іс пен іріктелмеген материалдардың (газеттер, бюллетеньдер, басқа да ресми партиялық басылымдар, естеліктер қолжазбалары мен біршама суреттер) 21 теңін құрайтын 3 мұрағат қорын түзді.

Кейін «ауызша тарихты» жинау жұмыстары тоқтатылды. Партия мұрағаты секторы партия және комсомол ұйымдарының, саяси бөлімдердің құжаттарын жинап, сақтады, өңдеді; сұраныс хаттар бойынша анықтамалар ұсынды, зерттеушілердің дереккөздерге қолжетімділігін ұйымдастырды (негізінен жоғарыда аталған институттың қызметкерлеріне). Партияның ғылыми қызметкерлері үстем партияның идеологтері қойған міндеттерге сәйкес революцияға дейінгі қазақ зиялылары туралы контрреволюциялық күшке табиғаты бойынша кертартпа деген пікірді жүйелі түрде қалыптастырды. Сөйтіп, жергілікті қазақ бұқарасының мүддесіне қарсы шықты. Мәселен, «Тарихшымарксист» журналында С. Брайни мен Ш. Шафиро былай деп жазған: «Борьба с идеализацией алашского движения для полной ее успешности требует от марксиста-исследователя ленинского разграничения между верхушечным движением и действительно массовым национально-революционном движении в Казахстане» (Пролетарская революция 1925).

1933 жылы желтоқсан айында Институтта алашордашылардың рөлі мен осы тақырыптағы С. Брайнин мен Ш. Шафироның «Алашорда тарихы бойынша очерктер» атты үшінші кітабын талқылауға арналған жиналыс өтті (За большевистское изучение истории ВКП (б) 1938: 38). Оның мақсаты - тарихи майданда «жеңіліске ұшыраған Алашорда өкілдеріне» теориялық тойтарыс беру. Шараның стенограммасы саяси ықпалдың көмегімен тарихи мәселеге ресми «ең дұрыс партиялық көзқарас» қалыптастырудың үлгісі болды 
Қызмет еткен жылдары Институт бірнеше мәрте қайта құрылды, соның салдарынан оның атауы мен бағыныстылығы да өзгерді. 1994 жылы Кеңес Одағы Коммунистік партиясы мұрағаты қорының бөлігі ҚР Президенті Мұрағатының құрамына енді. Оған дейін қор Қазақстан Коммунистік партиясы Орталық комитеті жанындағы Партия тарихы институтының Партия мұрағаты секторы мен Қазақстан Коммунистік партиясының Алматы мұрағатында сақталып келген (Большевик Казахстана 1935).

5. Осыған байланысты бүгінде ҚР Президенті Әкімшілігінде 1905-1917 жылдардағы революциялық оқиғалар мен Азамат соғысына қатысушылардың естеліктері, сондай-ақ КСРО, Қазақ КСР партиялық және мемлекеттік мұрағаттарындағы Институт қызметкерлері анықтаған XVIII-XX ғғ. құжаттардың көшірмелері сақтаулы. Мемуарлардан бөлек қорларда «М. Дулатовтың Өскемен уезіндегі саяси жағдай туралы Алашорда өкіметіне баяндама жазбасы» (1918); «Алаш» қозғалысы өкілдерінің қызметі туралы ОГПУ мәліметтері (Ә. Бөкейханов, А. Байтұрсынұлы, М. Дулатов және т.б.); алаш-ордашыларды тұтқындау жөніндегі телеграф әңгімелердің жазбасы (1922); Бақылау комиссиясы материалдарында алашордашылардың тізімі, «Алаш» қозғалысының қайраткерлері туралы мәліметтер (Ж. Ақпаев, Г. Әлібеков, А. Байтұрсынұлы, Ә. Бөкейханов, Х. Ғаббасов, М. Дулатов, С. Қаратілеуов, А. Кенжин, А. Қозбағаров, Р. Марсеков, Ғ. Тоқтабаев және т.б.) сақталған 4 .

Археографикалық құжаттар қорын құру. ҚР Президенті Мұрағаты Алаш партиясының құжаттары мен материалдары бойынша бірнеше басылымдар дайындады. Кеңестік режим кезінде «Алаш» партиясы мен қазақ комитеттеріне қатысты материалдар (1917-1918 жж.) зерттеушілер үшін жабық болатын. Сондықтан «Алаш қозғалысы» көптомдық жобасы үшін құжаттарды іріктеуде барынша мұрағат мәліметтері қағидаттарын ұстанды. Тақырыптар бойынша құжаттарды табылған жеріне қарамастан, бір басылымда жинақтауға талпыныс жасалды: ҚР ПӘ, ҚР Орталық мемлекеттік мұрағаты, Алматы облыстық мемлекеттік мұрағаты, Шығыс Қазақстан облысының Қазіргі заман құжаттамасы орталығы, Ұлттық Қауіпсіздік комитетінің мұрағаты; Ресей Федерациясы мұрағаттары (РФ Мемлекеттік мұрағаты, Әлеуметтік-саяси тарих мұрағаты), Ресей мемлекеттік әскери-тарихи мұрағаты, Томск облысы мұрағаты. Еңбекке Мұрағат материалдарымен қатар мерзімді баспасөз басылымдарының мақалалары енді.

«Алаш қозғалысы» 4 томдық басылымының 1-томында қозғалыстың құрылу себептерін ашатын, қазақ халқының өмірін қалайша жақсартамыз деген ұлт зиялыларының ізденістерін, Ресей империясының өмірін демократияландыру күресіне қатысуын, қазақ қоғамының ең прогресшіл күштерінің шоғырлануын, алаштықтардың көпұлтты Ресей зиялыларымен демократиялық өзара қарым-қатынастарын көрсететін 1901 жылдың сәуір айынан 1917 жылдың желтоқсан аралығындағы құжаттар мен материалдар жарияланған. Сондай-ақ «Алаш» партиясының бағдарламасы берілген.

2-томда Алашорда өкіметінің өз мақсаттарын жүзеге асыруда (Қазақ автономиясын құру) кездескен қиындықтар сипатталған. Ақтар қозғалысы өкілдерінің арасында одақтастар іздеу, Уақытша Сібір өкіметімен, Қомыш, Түркістан (Қоқанд) автономиясымен, башқұрт ұлшылдарымен, Оралдың әскери билігімен әскери-саяси одақ жасау алашордашыларды қандас бауырларын өлтірген азамат соғысының қатысушыларын жасады. Сол кезеңдегі большевизмнің идеологиялық үстемдігін мойындатқан Қызыл әскердің жеңісі олардың

${ }^{4}$ АП РК. Ф.811. - Оп.4. -Д.205. - Л.234-238 
Қазақ өлкесін басқару жөніндегі революциялық комитетпен, демек, кеңестік билікпен одағына әкелді.

3-томда ҚР Президенті Әкімшілігі мен ҚР ҰҚК Мұрағатында сақталған құжаттар басым, ішінара Ресей Әлеуметтік-саяси тарих мұрағатыныесей Әлеуметтік-саяси тарих мұрағатының құжаттары кездеседі. Том екі кітаптан тұрады, еңбекке 1920-1938 жж. аралығындағы құжаттар енген. Онда бас кезінде кеңестік қазақ мемлекеттілігі мен әлеуметтік-экономикалық құрылымдар құру үшін кең тартылған, кейін КСРО-да әкімшілік-топтық басқару жүйесі күшейген кезінде олардан бас тартқан қазақ зиялылары шоғырының қайғылы тағдыры сипатталған. Оның соңы алашордашыларды аяусыз жазалаумен аяқталды. Томдағы құжаттардың негізгі салмағын сол тұстағы элитаның бірбіріне жазған ашық әрі жабық арыздары құрайды, сондай-ақ республикадағы жағдайдың дамуына байланысты партиялық және кеңестік органдардың реакциясы мен саяси тактикасы туралы ауқымды материалдар берілген. Аталған кезең бойынша жарияланған дереккөздерге қосымша республиканың қалыптасуы кезеңінде елдің ішкі саяси дамуының табиғаты мен сипатын толығымен қайта құруға жол ашады.

Жинақта 1929-1932 жж. аралығындағы тергеулердің хаттамалары жарияланған. Құжаттар арасында М. Әуезов пен Ә. Ермековтің хаттары бар. Хатта ОГПУ-дің жәбірін көрген хаттың авторлары өз көзқарастарынан - «Алаш» партиясы идеологиясынан бас тартады. Коммунистер өз мүддесінен бұқара алдында бас тартуды оппозициялық партияларға қарсы үгіт-насихаттың маңызды бөлшегіне айналдырды. Оның мәні бұқараға ықпалы бар қандай болмасын топтың белгілі өкілдерін қадағалау тетіктерін (бойсұнушылық-пайдалылықтиімділік типі бойынша қатынастарды құру) қалыптастыру болды. 1934 жылы М. Әуезов пен Ә. Ермековтің өз «қателіктерін» мойындаған хаттары қазақстандық баспасөз беттерінде жарияланды. БКП (б) Қазақ өлкелік комитетінің қорындағы мәтіндерді анықтаған құрастырушылар сол тұстағы мерзімді баспасөздегі нұсқаларымен салыстырды. Қазақстанның археогра-фрикалық тәжірибесінде мұндай тәсіл алғаш рет қолданылды.

Қазақстан Республикасы Президенті Мұрағатының қорларында мына тақырыптар бойынша құжаттар қамтылған:

- Ресей Коммунистік партиясының Қырғыз облыстық комитеті;

- Бүкілодақтық Коммунистік партиясының Қазақ өлкелік комитеті;

- Бүкілодақтық коммунистік партиясының Қырғыз облыстық бақылау комиссиясы;

- Бүкілодақтық коммунистік партиясының Орталық комитеті жанындағы Уәкілетті партиялық бақылау комиссиясы;

- Бүкілодақтық компартияның Қазақ өлкелік бақылау комиссиясы;

- Қазақстан компартиясы ОК-нің Саяси зерттеулер институты.

Соңғы 4-том Алаш қозғалысын зерттеу мәселесіне арналған. БКП (б) Қазақ өлкелік комитетінің шешімдері, партиялық-кеңестік басшылардың әртүрлі форумдарда жасаған баяндамалары, Қазақстан Коммунистік партиясы Орталық комитеті жанындағы Партия тарихы институтының анықтамалары мен хаттары осы жинаққа енген. Алаш қозғалысының тарихына ресми көзқарастар түзілген аталған құжаттардан бірінші тарау құрастырылды. Онда «Ұлттық қозғалысты зерттеу мәселесі қашан қолға алынды, кімнің бастамасымен және кімдер зерттеді, оның нәтижелеріне биліктің көзқарасы қандай болды» деген сұрақтарға жауап табуға болады. Екінші тарауда 1933 және 1989 жылдардағы мәселелер бойынша конфреренциялар стенограммалары берілген. Бұл конференциялар Қазақстан КП ОК-нің жұмысын идеологиялық тұрғыдан 
қамтамасыз ететін мекеме қабырғасында өткізілген. Партия тарихшыларының тұжырымдаған көзқарастары ресми саналды. 1985 жылғы «қайта құру кезеңіне» дейін онымен ашық түрде келіспеу ең кемінде кәсіби тарихи қызметпен айналысу құқығынан айрылуды білдірді.

Үшінші тарауда 1918-2007 жылдар аралығындағы мерзімді баспасөз беттеріндегі мақалалар іріктеліп берілген. Жинаққа Алаш идеяларына ниеттестік танытқан тұлғалармен бірге, осы қозғалыстың өкілдері жазған ықшам да айқын материалдар енген. Олардың арасында 1918-1937 жылдары жазылған мақалалар басым, олардың бір бөлігі - библиографикалық тұрғыдан сирек кездесетін материалдар.

1997-2000 жылдары мұрағатшылар партия тарихының «ауызша тарих» тәсілі бойынша материалдар жинау дәстүріне қайта оралды. Жазулы мәтінде «Қайғылы тағдырлар беттері» (Брайнин 1934: 68) атты кітапта жарияланған. Айрықша жылнамаға қосымша ретінде отбасы суреттері берілген. Тарихи дереккөз ретінде фотоқұжаттардың барынша ақпараттылығын беру мақса-тында құрастырушылар XX ғасырдың бас кезінде саяси еркіндікке барған, сол үшін өз өмірін құрбан еткен ұлт зиялыларының жеке өкілдері туралы ақпаратты жан-жақты толықтырып беруге талпыныс жасаған. Нәтижесінде Ұлтық мұрағат қоры қудалауға ұшыраған Х.Досмұхамедұлы, М. Жұмабаев, А. Сейітов және т.б. ұрпақтарының жеке мұрағаттарынан алынған визуалды дереккөздермен толықты. Жарияланған мемуарлар өз кезегінде зерттеушілерге мәселені биліктің көзқарасын көрсететін мұрағат құжаттарын ғана емес, көз көргендердің естеліктерін зерттеу арқылы дәстүрлі тарихи нарративті еңсеруге мүмкіндік береді.

XX ғ. алғашқы ширегінің тарихына қатысты тақырыптық құжаттық жинақтармен қатар ҚР Президенті Мұрағаты сол дәуірдің тарихи тұлғалары бойынша басылымдар шығаруды қолға алды (Зулкашева 2009: 34). Жинақтардың алғашқылардың бірі 1937 жылы қуғын-сүргінге ұшыраған, «Алаш» партиясының мүшесі Ә. Әлібековке арналды. Бұл еңбек Ә. Әлібековтің жеке қорындағы құжаттары негізінде түзілді. Құжаттарды 2004 жылы мамыр айында Д. Қонаев Халықаралық қоры бас директорының орынбасары, тұлғаның шөбересі Л. Сейфуллина мұрағатқа табыс еткен. Құрастырушылар «Алаш қозғалысы» еңбегіне енбеген құжаттарды жариялады, атап айтсақ, Бүкілресейлік жоғары биліктің жаңа өкіметін - кеңестік биліктен елді азат ету үшін күреске арналған директорияны құрған, 1918 жылы күз мезгілінде Уфра мәжілісінде табысталған, Қазақ өлкесін басқару жөніндегі Әскери комитеттің мүшесі Г. Әлібековтің контрреволюциялық қызметі туралы орталық партиялық органға өтініші. Мұндай тәубеге келу өтініштері мен хаттардың кеңестік феномені большевиктердің келуімен жазылды. Бұрынғы партияластарға айтылған сындар билік алдында адалдықты көрсету еді. Құжаттардан бөлек жарияланғандардың арасында Алаш қозғалысы тарихын зерттеушілердің назарын отбасы мұрағатынан алынған суреттер қызығушылық тудыратыны сөзсіз.

«Төтенше комиссар» жинағында екі топтың өкілдері Ә. Жангелдин мен Ә.Бөкейхановтың қарым-қатынасын сипаттайтын құжаттар бар. «Революциядан кейін басқа да көптеген жанұялар секілді біздің үй ішімізде де бәрі күрт өзгерді: «қызылы» да, «ағы» да. Тарих бетбұрысында олардың әрқайсысы қазақ халқының еркін де тәуелсіз болғанын қалады Олар ең алдымен өз мемлекеттілігін құруды көздеді» - деп жазды Шыңғыс - Ә. Жангелдиннің ұлы, А. Кенжиннің немересі (Грибанова, 2010: 33). Қалыптасқан дәстүр бойынша БАҚ-тағы құжаттық басылымдармен жұмыс шеңберінде мұрағатшылар фотоқұжаттар жинаудан бастайды. Мәселен, аталған басылымда 1921 жылғы КАКСР Кеңес наркомы мүшелерінің белгілі суреті жарияланған. Олардың арасында А. Байтұрсынұлы мен Ә. Әлібеков 
бар. Сондай-ақ 1923 жылғы Қырғыз ЦИК және Кеңес наркомы мүшелерінің өте сирек суреті кездеседі, олардың арасында К. Тоқтабаев пен А. Кенжин отбасының суреті бар (Ш. Жангелдиннің жекемұрағатынан).

ҚР Президентінің Әкімшілігіне Алаш тарихына қатысты құжаттар құрамы өз идеологиялық қарсыластарының қызметін айыптаған партиялық басқарушы режим органдарының қаулыларынан, ОГПУ, ҰҚК анықтамаларынан, 1920 жылдары мемлекеттік қызметке уақытша қабылданған алашордашылдардың жеке істерінен ғана емес, сондай-ақ мемлекеттік мұрағаттардан көшіріліп алынған мұрағат дереккөздерінен, мерзімді баспасөз мақалаларының көшірмелерінен, аталған дереккөздермен жұмыс істеуге рұқсат етілген тарихшылар осы мәселелерді талқылауға қатысты мәжілістер, конференциялар мен дөңгелек үстелдер стенограммалары, хаттамаларынан, оның ішінде ең маңыздысы, Алаш қозғалысы қайраткерлерінің отбасылық мұрағатында сақталған фотоқұжаттардан тұрады.

«Алаш қозғалысы» жобасында құрастырушылар төмендегідей құжаттар тобын жариялады (1-диаграмма).

\section{Документы АП РК по истории движения Алаш \\ -Письма "во власть"}

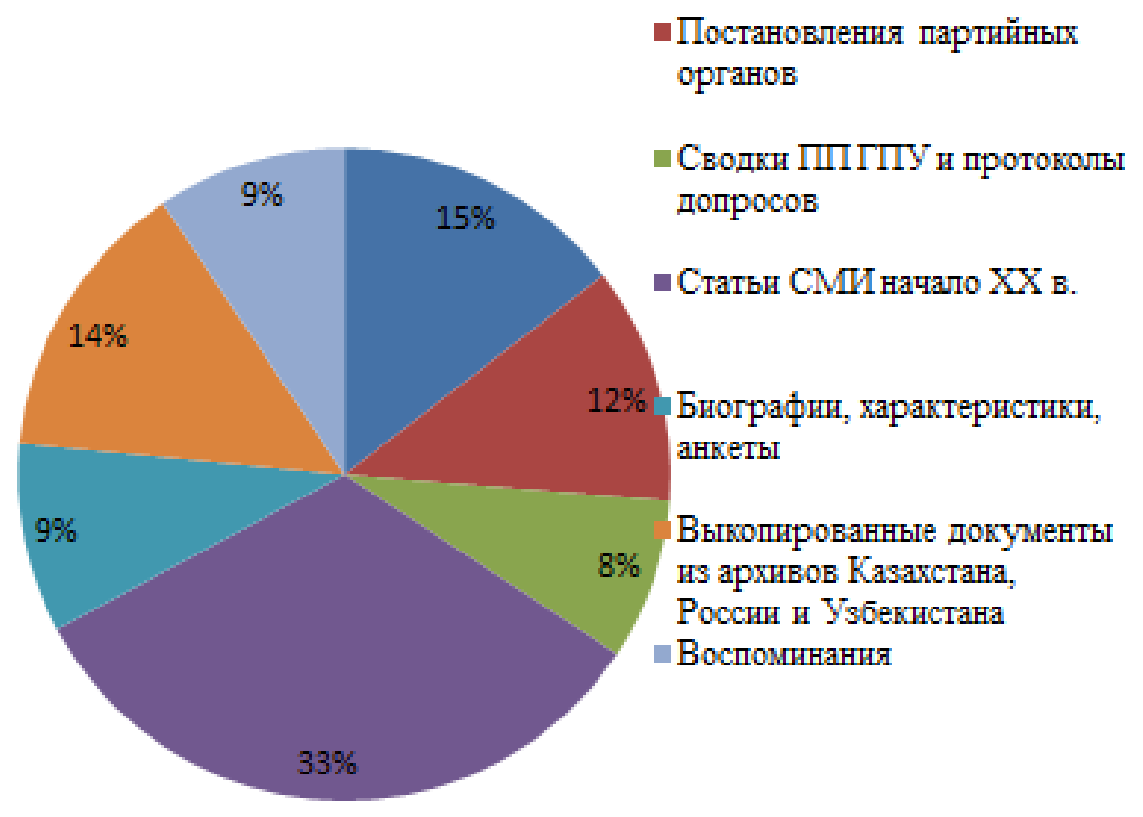

1-диаграмма. Алаш қозғалысының тарихына қатысты құжаттар

Қорытынды. Алаш тарихы және XX ғасырдың бірінші ширегіндегі ұлт зиялыларының тағдыры отандық тарихнамада өзекті мәселе болып қала бермек. Осыған орай зерттеулердің дереккөздік базасына және бұрын белгісіз болып келген мұрағат материалдарын анықтап, оны ғылыми айналымға енгізуге қызығушылық толастамай отыр. Осы тұрғыдан ҚР Президенті Мұрағатының қоры зерттеуші тарихшылар үшін қызықты. Мұрағатта сұраныс жоқ мемуарлық дереккөздердің елеулі үлесі сақталған. Сонымен қатар басқа да жазба дереккөздермен толықтырылған дәл осы естеліктер тарихи жұмыстардың ғылыми мазмұнын жаңаша толықтыруы мүмкін әрі сол тұста елімізде болған күрделі әлеуметтік-саяси, партияішілік және этносаяси үдерістерді талдауға мүмкіндік және кешенді түсінік береді. Ол үшін 
ҚР Президенті Мұрағаты басып шығарған құжаттық жинақтар фрактологиялық база болып табылады.

2016 жылдан бері осы Алаш тарихына байланысты көптеген жұмыстар атқарылып келеді. Алаш қозғалысының 100 жылыдығына орай ҚР Президенті Архиві қызметкерлерінің қатысуыменде көптеген іс-шаралар жүргізілді. Атап өтетін болсақ:

- Ә. Бөкейхановтың 150 жылдығына арналған «Еуразияның түркі және мұсылман халықтарының саяси көшбасшылары: тұлғалар, идеялар, тағдырлар, XX ғасырдың басы» тақырыбындағы халықаралық ғылыми-тәжірибелік конференция болды.

-Алаш қайраткері Асылбек Сейітовтың қызы Клара Сейітовадан әкесінің өмірі мен қызметіне қатысты естелік жазып алынды.

-«Түркістан - түркі әлемінің мәдени астанасы» іс-шарасы аясында «Алаштану және музей» ғылыми-тәжірибелік конференциясы, сонымен қатар «Алаштың айбынды ұлдары» фотокөрмелері ұйымдастырылды.

-«Тәуелсіздік тағылымы: Батыс Алаш Орда тарихынан» атты тақырыпта дөңгелек үстел ұйымдастырылды.

-«Алаш қозғалысының тарихы ҚР Президенті Архивінің құжаттары мен материалдарында» тақырыбында №165 мамандандырылған лицейінде дәріс оқытылды, және де Т. Рысқұлов атындағы ҚазЭУ студенттеріне дәріс сабақтары жүргізілді.

-«Алаш қозғалысы: тарихы, зерттелуі жаңа ізденістер», «Ғасырлар тоғысындағы Алаш идеялары», «Алаш - қазақтың ұлттық тұтастық идеясы» атты халықаралық конференциялар ұйымдастырылды.

-Аспандияр Кенжиннің 130 жылдығына арналған «Ғасырлар тоғысындағы тағдыр» атты еске алу кеші ұйымдастырылды.

Қорытылай келгенде, Алаш тарихы мұнымен бітпейді, рухани жаңғыруда. Алаш тарихы жалғасады. Рухани жаңғыруда кешегі заман мен бүгінгі заманның түйген тәжірибесі, ол өз елін, туған жерін сүю, оның көркеюіне жол ашады, ұрпақтар сабақтастығын одан әрі дамытады. Рухани жаңғырудың еліміздің идеологиялық тірегі екеніне көңіл аударғымыз келеді.

\section{Әдебиеттер тізімі/ Список литературы}

1. Архив Президента Республики Казахстан. Путеводитель: справочно-информационное издание / Сост. Грибанова Е.М. - Алматы: Жеті жарғы, 2001. - 164 с.

2. Брайнин С., Шафиро Ш. Против идеализации и управленческого понимания исторического прошлого алашского движения // Историк-марксист - 1934. - №2 (36) - С.68. Цит. по статье Садвокасовой 3.Т. Диффреренциация представителей казахской интеллигенции / Материалы Международной научно-практической конференции: Алаш и независимый Казахстан: преемственность идей и позиций. 21 ноября 2008. - Алматы: Абай атындағы Қаз ҰПҮ, 2008.

3. В.И. Ленин и первые годы Советской власти // Вопросы истории КПСС (Москва). -1960. - №6.

4. Волобуев П.В. Вступительное слово // Революция и человек. Быт. Нравы. Поведение и мораль. M.: PAH, 1997. - 223 c.

5. Грибанова Е.М. Обзор археографической продукции и справочно-информационных изданий за 1994-2010 гг. (СИФ1662) - Алматы: АПРК, 2010. - 33 с.

6. Гелис И. Как надо писать воспоминания // Пролетарская революция. - 1925. - №7.

7. Антропов П. Что и как читать по истории революционного движения и партии в Средней Азии. Самарканд, 1929.

8. Зулкашева А.С. Приемы реконструкции текста на примере «Стенограммы заседания сектора истории КНИИМЛа 8-28 декабря 1933 г., посвященного контрреволюционной роли Алаш-Орды / Пути использования... Указ. соч. - С.34-48. Сборник документов (1916-1923). - Алматы: Print Express, 2009. - 228 c.

9. Источниковедение России. - М.: РГУ, 2015. - 702 с.; 
10. Медушевская, Румянцева М.Ф. Методология истории: Учебное пособие. - М., РГГУ, 1997. - 72 с.

11. Казахстан к десятилетию Октября. Сборник статей и материалов. - Кызыл-Орда, 1927. - 76с.; Из истории гражданской войны в Казахстане. - Кызыл-Орда, 1927.; Октябрь в Казахстане. - Алма-Ата, 1930.

12. Красная летопись Туркестана. - Ташкент, 1923. - №1-2. - С.3.

13. Культурное строительство в Казахстане. Сборник документов и материалов. 1918-1932. - Т.1. Алма-Ата: Казахстан, 1965. - 566с. - С.318.

14. Покровский М.Н. Противоречия г. Милюкова // Интеллигенция и революция. Сборник статей. - М.: Дом печати, 1922.

15. Покровский М.Н. Очередные задачи историков-марксистов // Историческая наука и борьба классов. Вып. 2. - М.-Л., 1933.

16. Авдеев Н. О научной обработке источников по истории РКП (б) и Октябрьской революции // Пролетарская революция. - 1925. - №1-2. - С.149-160.

17. Покровский М.Н. Двадцатилетие нашей первой пролетарской революции // Пролетарская революция. - 1924. -№11(34).

18. Минц И.И. Борьба за Советы (1918-1919) // Пролетарская революция. - 1927. - № 1.

19. Ольминский М.С. О мемуарах. // Из эпохи "Звезды" и «Правды». - М., 1921.

20. Пролетарская революция // 1923. - №8.

21. От истпарта // Пролетарская революция. - 1921. - №1.

22. Революция в Средней Азии. Сб.1. - Ташкент: Правда Востока, 1928.

23. Речь Кагановича на торжественном заседании, посвященном десятилетнему юбилею И.К.П. // За

большевистское изучение истории ВКП (б)... - Москва: Политиздат, 1938.

24. Сейорулин С. Тернистый путь - Алма-Ата: Жазушы, 1975. - 432 с.

25. Страницы трагических судеб: сб. воспоминаний жертв политических репрессий в СССР в 19201950-е гт. - Алматы: Жеті жарғы, 2002. - 448 с.

26. Тартаковский А.Г. Военная публицистика 1812 года. - М.: Мысль, 1967. - 222 с.

27. Тартаковский А.Г. 1812 год и русская мемуаристика: Опыт источниковедческого изучения. - М.: Наука, 1980. -312с.

28. Тартаковский А.Г. Русская мемуаристика XVIII - первой половины XIX вв.: от рукописи к книге. - М.: Наука, 1991. -286 с.

29. Утепов Ш. О книгах Брайнина и Шафиро - «Очерки по истории Алаш-Орды» и «Первые шаги Советов в Семиречье»// Большевик Казахстана. - 1935. - №6. - С.87-91.

30. Чиликова Е.В. Опервых публикаторах Советского Казахстана, изучавших историю движения Алаш / Пути использования и совершенствования современных научно-практических приемов и методов в работе с архивными материалами. Материалы республиканского учебно-практического семинара. Астана, 2007. - С.23-33.

31. Чрезвычайный комиссар: к 125-летию Алиби Джангильдина. Сборник документов. - Алматы: Print Express, 2009.

\section{Reference}

Arhiv Prezidenta Respubliki 2001 - Arhiv Prezidenta Respubliki Kazahstan. Putevoditel': spravochnoinformacionnoe izdanie 2001, Sost. Gribanova, EM, ZHeti zharny, Almaty, 164 s. (Archive of the President of the Republic of Kazakhstan. Guide: reference and information publication 2001, Comp. Gribanova, EM, ZHeti zharny, Almaty, 164 p). (in Rus).

Brajnin, SHafiro 2008 - Brajnin, S, SHafiro, Sh 1934, Protiv idealizacii i upravlencheskogo ponimaniya istoricheskogo proshlogo alashskogo dvizheniya, Istorik-marksist, №2(36). Cit. po stat'e Sadvokasovoj, ZT 2008, Differenciaciya predstavitelej kazahskoj intelligencii, Materialy Mezhdunarodnoj nauchno-prakticheskoj konferencii: Alash i nezavisimyj Kazahstan: preemstvennost' idej i pozicij. 21 noyabrya 2008, Abaj atyndagy Kaz UPU, Almaty. (Brajnin, S, SHafiro, Sh, 1934, Against idealization and administrative understanding of the historical past of the Alash movement, Marxist Historian, №2(36). Cit. po stat'e Sadvokasovoj, ZT 2008, Differentiation of representatives of the Kazakh intelligentsia, Materials of the International scientific and practical conference: Alash and independent Kazakhstan: continuity of ideas and positions. November 21, 2008, Abaj atyndagy Kaz UPU, Almaty). (in Rus).

Lenin i pervye gody 1960 - V.I. Lenin and the first years of Soviet power, Voprosy istorii KPSS (Moskva) 1960, №6. (V.I. Lenin i pervye gody Sovetskoj vlasti, Questions of history of the CPSU (Moscow) 1960, №6). (in Rus).

Volobuev 1997 - Volobuev, PV 1997, Vstupitel'noe slovo, Revolyuciya i chelovek. Byt. Nravy. Povedenie i moral', RAN, Moscow, 223 s. (Volobuev, PV 1997, Opening remarks, the revolution and the people. Gen. Mores. Behavior and morality, RAN, Moscow, 223 p). (in Rus). 
Gribanova 2010 - Gribanova, EM 2010, Obzor arheograficheskoj produkcii i spravochnoinformacionnyh izdanij za 1994-2010 gg. (SIF1662), AP RK, Almaty, 33 s. (Gribanova, EM 2010, Overview of the archaeological product and the reference edition for 1994-2010. (СИФ1662), AP RK, Almaty, 33 p). (in Rus).

Gelis 1925 - Gelis, I 1925, Kak nado pisat' vospominaniya, Proletarskaya revolyuciya, №7. (Gelis, I 1925, How to write memories, Proletarian revolution, №7). (in Rus).

Antropov 1929 - Antropov, P 1929, CHto i kak chitat' po istorii revolyucionnogo dvizheniya $i$ partii $v$ Srednej Azii, Samarkand. (Antropov, P 1929, What and how to read the history of the revolutionary movement and the party in Central Asia, Samarkand). (in Rus).

Zulkasheva 2009 - Zulkasheva, AS 2009, Priemy rekonstrukcii teksta na primere «Stenogrammy zasedaniya sektora istorii KNIIMLa 8-28 dekabrya 1933 g., posvyashchennogo kontrrevolyucionnoj roli Alash-Ordy, Puti ispol'zovaniya... Sbornik dokumentov (1916-1923), Print Express, Almaty, 228 s. (Zulkasheva, AS 2009, Techniques of reconstruction on the example of the "Transcript of the meeting of the Department of the history of Knime 8-28 December 1933, dedicated to the counter-revolutionary role of Alash Orda, The use of... the Decree (1916-1923), Print Express, Almaty, 228 p). (in Rus).

Istochnikovedenie Rossii 2015 - Istochnikovedenie Rossii, RGU, Moscow, 702 s. (Source Studies of Russia, RGU, Moscow, 702 p). (in Rus).

Medushevskaya, Rumyanceva 1997 - Medushevskaya, Rumyanceva, MF 1997, Metodologiya istorii: Uchebnoe posobie, RGGU, Moscow, 1997, 72 s. (Medushevskaya, Rumyanceva, MF 1997, Methodology of history: a Training book, RGGU, Moscow, 1997, 72 p). (in Rus).

Kazahstan k desyatiletiyu Oktyabrya 1930 - Kazahstan k desyatiletiyu Oktyabrya. Sbornik statej i materialov 1927, Kyzyl-Orda, 76 s. (Kazakhstan on the tenth anniversary of October. Collection of articles and materials 1927, Kyzyl-Orda, 76 p). (in Rus).

Iz istorii grazhdanskoj vojny 1927 - Iz istorii grazhdanskoj vojny v Kazahstane 1927, Kyzyl-Orda. (From the history of the civil war in Kazakhstan 1927, Kyzyl-Orda). (in Rus).

Oktyabr' v Kazahstane 1930 - Oktyabr' v Kazahstane 1930, Alma-Ata. (Oktyabr' v Kazahstane 1930, Alma-Ata). (in Rus).

Krasnaya letopis' Turkestana 1923 - Krasnaya letopis' Turkestana 1923, Tashkent, №1-2. (Red chronicle of Turkestan 1923, Tashkent, №1-2). (in Rus).

Kul'turnoe stroitel'stvo 1965 - Cultural construction in Kazakhstan. Collection of documents and materials. 1918-1932 1965, Alma-Ata: Kazahstan, T.1, 566s. (). (in Rus).

Pokrovskij 1922 - Pokrovskij, MN 1922, Protivorechiya g. Milyukova, Intelligenciya i revolyuciya. Sbornik statej, Dom pechati, Moscow. (Pokrovskij, MN 1922, Milyukov's contradictions, Intelligentsia and revolution. Collected papers, Dom pechati, Moscow). (in Rus).

Pokrovskij 1933 - Pokrovskij, MN 1933, The next tasks of historians-Marxists, Historical science and the struggle of classes, Vyp. 2, Moscow-Leningrad. (Pokrovskij, MN 1933, The next tasks of historians-Marxists, Historical science and the struggle of classes, Vyp. 2, Moscow-Leningrad). (in Rus).

Avdeev 1925 - Avdeev, N 1925, O nauchnoj obrabotke istochnikov po istorii RKP (b) i Oktyabr'skoj revolyucii, Proletarskaya revolyuciya, №1-2, S.149-160. (Avdeev, N 1925, On the scientific processing of sources on the history of the RCP (b) and the October revolution, Proletarian revolution №1-2, S.149-160). (in Rus).

Pokrovskij 1924 - Pokrovskij, MN 1924, Dvadcatiletie nashej pervoj proletarskoj revolyucii, Proletarskaya revolyuciya, №11(34). (Pokrovskij, MN 1924, The twentieth anniversary of our first proletarian revolution, Proletarian revolution, №11(34)). (in Rus).

Minc 1927 - Minc, 1927, Bor'ba za Sovety (1918-1919), Proletarskaya revolyuciya, № 1. (Minc 1927, The Struggle for the Council (1918-1919), Proletarian revolution, № 1). (in Rus).

Ol'minskij 1921 - Ol'minskij, MS 1921, O memuarah, Iz ehpohi «Zvezdy» $i$ «Pravdy», Moscow. (Ol'minskij, MS 1921, About memoirs, From the era of «Star» and «Truth», Moscow). (in Rus).

Proletarskaya revolyuciya 1923 - Proletarskaya revolyuciya 1923, №8. (Proletarian revolution 1923, №8). (in Rus).

Ot istparta 1921 - Ot istparta, Proletarskaya revolyuciya 1921, №1. (Ot istparta, Proletarian revolution 1921, №1).(in Rus).

Revolyuciya v Srednej Azii 1928 - Revolyuciya v Srednej Azii. Sb.1 1928, Pravda Vostoka, Tashkent. (Revolution in Central Asia. Sb.1 1928, Pravda Vostoka, Tashkent). (in Rus).

Rech' Kaganovicha 1938 - Rech' Kaganovicha na torzhestvennom zasedanii, posvyashchennom desyatiletnemu yubileyu I.K.P., Za bol'shevistskoe izuchenie istorii VKP (b)... 1938, Politizdat, Moskva. (Kaganovich speech at a solemn meeting dedicated to the tenth anniversary of I. K. P., For the Bolshevik study of the history of the CPSU (b)... 1938, Politizdat, Moskva). (in Rus).

Sejfullin 1975 - Sejfullin, S 1975, Ternistyj put', ZHazushy, Alma-Ata, 432 s. (Sejfullin, S 1975, Thorny way, ZHazushy, Alma-Ata, 432 s). (in Rus). 
Stranicy tragicheskih sudeb 2002 - Stranicy tragicheskih sudeb: sb. vospominanij zhertv politicheskih repressij v SSSR v 1920-1950-e gg 2002, ZHeti zhargy, Almaty, 448 s. (Page tragic fates: a collection of memoirs of victims of political repressions in the USSR in 1920-1950-ies 2002, ZHeti zhargy, Almaty, $448 \mathrm{~s})$. (in Rus).

Tartakovskij 1967 - Tartakovskij, AG 1967, Voennaya publicistika 1812 goda, Mysl', Moscow, 222 s. (Tartakovskij, AG 1967, Military journalism of 1812, Mysl', Moscow, 222 s). (in Rus).

Tartakovskij 1980 - Tartakovskij, AG 1980, 1812 god i russkaya memuaristika: Opyt istochnikovedcheskogo izucheniya, Nauka, Moscow, 312s. (Tartakovskij, AG 1980, 1812, and the Russian memoirs: the Experience of source study, Nauka, Moscow, 312s). (in Rus).

Tartakovskij 1991 - Tartakovskij, AG 1991, Russkaya memuaristika XVIII - pervoj poloviny XIX vv.: ot rukopisi k knige, Nauka, Moscow, 286 s. (Tartakovskij, AG 1991, Russian memoirs of the XVIII-th century: from the manuscript to the book, Nauka, Moscow, $286 \mathrm{~s}$ ). (in Rus).

Utepov 1935 - Utepov, Sh 1935, O knigah Brajnina i SHafiro - «Ocherki po istorii Alash-Ordy» i «Pervye shagi Sovetov v Semirech'e», Bol'shevik Kazahstana, №6, S.87-91. (Utepov, Sh 1935, About books Brainin and Shapiro - «Essays on the history of Alash Orda» and "First steps of Soviets in semirech'e», Bol'shevik Kazahstana, №6, P.87-91). (in Rus).

CHilikova 2007 - CHilikova, EV 2007, O pervyh publikatorah Sovetskogo Kazahstana, izuchavshih istoriyu dvizheniya Alash, Puti ispol'zovaniya $i$ sovershenstvovaniya sovremennyh nauchnoprakticheskih priemov i metodov $v$ rabote $s$ arhivnymi materialami. Materialy respublikanskogo uchebno-prakticheskogo seminara, Astana, S.23-33. (CHilikova, EV 2007, About the first publishers of the Soviet Kazakhstan who studied history of the movement of Alash, Ways of use and improvement of modern scientific and practical methods and methods in work with archival materials. Materials of the Republican educational and practical seminar, Astana, S.23-33). (in Rus).

CHrezvychajnyj komissar 2009 - CHrezvychajnyj komissar: k 125-letiyu Alibi Dzhangil'dina. Sbornik dokumentov, Print Express, Almaty. (Emergency Commissioner: to the 125th anniversary of the Alibi Dzhangildin. Collection of documents, Print Express, Almaty). (in Rus). 